\title{
PEMBELAJARAN MENGANALISIS STRUKTUR DAN KEBAHASAAN TEKS EKSPOSISI DENGAN METODE THINK PAIR AND SHARE UNTUK MENINGKATKAN KEMAMPUAN BERPIKIR KRITIS PADA PESERTA DIDIK KELAS X SMAN 6 BANDUNG TAHUN PELAJARAN 2018/2019
}

\author{
Eggie Nugraha ${ }^{1}$, Ari Heriyanto ${ }^{2}$ \\ 1,2FKIP Unpas \\ 1eggienugraha@unpas.ac.id, ${ }^{2}$ Ariheriyanto12@gmail.com
}

\begin{abstract}
Learning to analyze the structure and linguistic exposition text is part of reading skills by optimizing critical thinking skills. The research results that have been carried out by the authors are: 1) The first hypothesis is accepted. The author gets the average value of learning implementation is $3.65 ; 2)$ The second hypothesis is accepted. This can be proven by the results of the experimental class pretest average score of 27.14 and the experimental class posttest value of 82.28; 3) The third hypothesis is accepted. This can be proven based on the results of the $t$ test data, obtained a degree of freedom of 24 with a 95\% confidence level and a significant level of $5 \%$ with the results of t count $>t$ table. 4) The fourth hypothesis is accepted. The pretest data in the experimental class is a minimum score of 14.29, a maximum score of 42.86, a total value of 678.59 and a mean value of 27.14. Posttest data in the experimental class got a minimum score of 71.43, a maximum score of 92.86, a total value of 2057.11 and a mean value of 82.28. The pretest data in the control class obtained a minimum score of 0 , a maximum score of 42.86, a total value of 450 and a mean value of 18 . The posttest value of the experimental class with a minimum score of 35.71, a maximum score of 85.71 , a total value of 1478.55 , and the mean value is 59.14 ; 5) The fifth hypothesis is accepted. The experimental class gets an average value of 82.28 , an average value of $59.14 ; 6$ ) The sixth hypothesis is accepted. In the experimental class, the average score obtained from the observation sheets of critical thinking skills of students was 25 people including in the good category (B). Based on these data, the authors conclude that analyzing the structure and language of the exposition text with the think pair and share method to improve the critical thinking skills of class $X$ students successfully.
\end{abstract}

Keywords: Reading, think pair and share, learning, exposition text,.

\section{ABSTRAK}

Pembelajaran menganalisis struktur dan kebahasaan teks eksposisi merupakan bagian dari keterampilan membaca dengan mengoptimalkan kemampuan berpikir secara kritis. Hasil penelitian yang telah dilaksanakan penulis ialah: 1) Hipotesis pertama diterima. Penulis mendapatkan nilai rata-rata pelaksanaan pembelajaran adalah 3.65 ; 2) Hipotesis kedua diterima. Hal ini dapat dibuktikan dengan hasil dari nilai rata-rata pretes kelas eksperimen 27,14 dan nilai 
rata-rata postes kelas eksperimen 82,28 ; 3 ) Hipotesis ketiga diterima. Hal ini dapat dibuktikan berdasarkan hasil data uji $t$, diperoleh derajat kebebasan sebesar 24 dengan tingkat kepercarayaan $95 \%$ dan taraf signifikan 5\% dengan hasil thitung >ttabel. 4) Hipotesis keempat diterima. Data pretes pada kelas eksperimen ialah skor minimal sebesar 14,29 , skor maksimal sebesar 42,86 , nilai total sebesar 678,59 dan nilai mean sebesar 27,14. Data postes pada kelas eksperimen mendapatkan hasil skor minimal sebesar 71,43 , skor maksimal sebesar 92,86, nilai total sebesar 2057,11 dan nilai mean sebesar 82,28. Data pretes pada kelas kontrol didapatkan hasil skor minimal sebesar 0 , skor maksimal sebesar 42,86 , nilai total sebesar 450 dan nilai mean sebesar 18 . Nilai postes kelas eksperimen dengan skor minimal sebesar 35,71 , skor maksimun 85,71 , nilai total sebesar 1478,55 , dan nilai mean sebesar 59,14 ; 5) Hipotesis kelima diterima. Kelas eksperimen mendapatkan nilai rata-rata sebesar 82,28 , nilai rata-rata 59,14 ; 6) Hipotesis keenam diterima. Pada kelas eksperimen, rata-rata perolehan skor dari lembar pengamatan kemampuan berpikir kritis peserta didik sebanyak 25 orang termasuk pada kategori baik (B). Berdasarkan data tersebut, penulis menyimpulkan bahwa menganalisis struktur dan kebahasaan teks eksposisi dengan metode think pair and share untuk meningkatkan kemampuan berpikir kritis peserta didik kelas $\mathrm{X}$ berhasil.

Kata kunci: Membaca, pembelajaran, think pair and share, teks eksposisi.

\section{A. PENDAHULUAN}

Belajar merupakan sebuah proses mendapatkan wawasan tentang pengetahuan, tingkah laku, dan kemampuam baru guna meningkatkan pola hidup dan ber-pikir manusia agar mampu menyesuaikan diri dengan tuntutan sosial dalam hidup bermasyarakat. Setiap manusia memiliki cara belajar yang sesuai dengan karakternya masing-masing. Sehinnga, kemampuan dan wawasan setiap individu berbeda. Kokom (2013, hlm. 1) menyatakan, "Hasil belajar ialah perubahan sese-orang yang asalanya tidak tahu menjadi tahu". Ketidaktahuan akan suatu hal dapat didapat melalui proses belajar.
Seseorang yang memiliki ilmu tak lepas dari proses belajar jangka panjang dan kompleks. Tidak semua orang mampu menjalani proses belajar secara efektif untuk mencapai tujuan pembelajaran.

Pemerintah dalam meningkatkan pendidikan yang baik bagi para peserta didik merumuskan landasanIndasan yang dijadikan pedoman bagi para pendidik untuk mencapai tujuan belajar yaitu kurikulum. kurikulum yang berlaku di Indo-nesia saat ini ialah Kurikulum 2013. Kurikulum 2013 menjadi pedoman penyelenggaraan kegiatan pembela-jaran untuk mencapai tujuan pendi-dikan tertentu. 
Pengajaran Bahasa dan Sastra Indonesia dalam kurikulum 2013 sangat diperhatikan dan dioptimalkan, terbukti dengan porsi jam pelajaran yang lebih banyak dari pelajaran lain. Bahasa Indonesia merupakan pengajaran yang sangat penting di Indonesia. Tarigan (2008, $\mathrm{hlm}$. 1) mengatakan "Semakin terampil seseorang berbahasa, semakin cerah dan jelas pula jalan pikirannya", sehingga seseorang diwajibkan untuk terampil dalam berbahasa agar tahu cara mengarahkan pemikiran dan tindak tutur dalam kehidupannya. Pengajaran yang dilakukan tak lepas dari keterampilan berbahasa antara pendidik dan peserta didik. Tentunya, keteram-pilan berbahasa harus mendapatkan perhatian yang lebih spesifik terhadap keterampilan berbahasa yang meliputi keterampilan menyimak, berbicara, membaca, dan menulis. Keterampilan membaca merupakan salah satu keterampilan berbahasa yang digunakan oleh pengguna bahasa untuk mendapat-kan informasi yang ingin didapatkan. Sehingga, kegiatan membaca merupakan keharusan bagi setiap pengguna bahasa untuk memperluas pengetahuan agar bisa menyesuaikan diri dengan kehidupan bermasyarakat. Kenyataan saat ini, masyarakat khususnya peserta didik cenderung mangabaikan kegiatan membaca karena kurangnya stimulus/minat yang diberikan dari segi model pembelajaran maupun dari segi minat peserta didik itu sendiri yang secara tidak langsung kegiatan membaca mampu meningkatkan daya nalar/berpikir pembaca dan menambah informasi dari setiap buku yang dibacanya. Tampubolon (1990, hlm. 7) mengatakan "Selain memperkaya pengetahuan, membaca lanjut juga meningkatkan daya nalar atau proses kognitif", dengan kegiatan membaca lanjut, pembaca mampu meningkatkan daya berpikir/nalar yang lebih baik dibandingkan dengan pembaca singkat guna mendapatkan informasi yang lebih menyeluruh.

Hasil pengamatan penulis dari proses praktik pengenalan lapangan dengan melakukan kegiatan mengajar di SMAN 6 Bandung pen-didik menemukan masalah minat baca peserta didik yang mempe-ngaruhi semangat berpikir sehingga siswa kesulitan dalam mengambil informasi penting dari setiap pelajaran yang 
diterima. Sehingga, dari permasalahan inilah para pendi-dik harus kreatif dalam melakukan kegiatan pembelajaran agar membangkitkan motivasi dan daya nalar peserta didik dalam belajar dan membaca agar memperoleh informasi secara cepat dan matang.

Motivasi berpikir peserta didik pada saat ini sangatlah kurang. Terbukti dengan hasil pengamatan pribadi penulis saat melakukan kegiatan mengajar. Peserta didik cenderung menghindari kegiatan berpi-kir secara mendalam karena pemiki-ran mereka yang ingin mendapatkan sesuatu hal dengan instan. Hal tersebut berdampak pada pengetahuan dan hasil belajar peserta didik yang tidak menyeluruh dan optimal. Pada dasarnya, sebagai peserta didik mereka harus melatih daya nalar atau berpikir secara kritis agar mereka terbiasa dengan permasalahan-permasalahan yang akan timbul di kehidupan bermasyarakat.

Pada kesempatan ini, penulis akan berusaha melakukan penelitian berupa kegiatan menganalisis sebuah teks dengan tahap membaca kritis untuk mendapatkan informasi yang lebih lengkap dan tepat, pembaca tidak hanya melakukan kegiatan membaca yang biasa saja, kerena membaca biasa hanya akan memberikan pemahaman yang tidak lengkap dan tepat. Albert (Tarigan, thn. 2008, hlm. 92) mengatakan "membaca kritis merupakan sejenis membaca yang dilakukan secara bijaksana, penuh tenggang hati, mendalam, evaluatif, serta analitis, dan bukan hanya mencari kesalahan". Sehingga membaca kritis meruakan sebuah keterampilan untuk mendapatkan informasi yang tepat, akurat dan efektif untuk kegiatan menganalisis.

Teks eksposisi merupakan teks yang berisi pendapat yang berisfat argumenttatif. Akan tetapi, peserta didik masih saja kurang memhami cara menilai dan menanggapi sebuah argumen yang mereka temukan. Sehingga, untuk mendapatkan informasi yang matang dari teks argumentasi diperlukan pembacaan yang seksama karena harus menelaah secara kritis mengenai pendapat-pendapat yang terkandung dalam teks eksposisi tersebut. Peserta didik juga belum bisa memahami cara menganalisis sebuah teks karena kurangnya pemahaman 
mengenai struktur yang digunakan dalam sebuah teks dikarenakan kurangnya kegiatan membaca. Penulis beren-cana untuk menjadikan peserta didik yang kreatif dalam memahami karya tulis dengan menggunakan metode pembelajaran yang kreatif dan efektif agar meningkatkan daya nalar dan berpikir peserta didik. Mereka ditun-tut untuk mencari dan menyelididki secara sistematis, kritis, logis, ana-litis, sehingga peserta didik dapat merumuskan penemuannya dengan terlibat langsung dalam proses dan kegiatan belajar.

Berdasarkan uraian diatas, penulis termotivasi untuk melakukan penelitian yang berjudul "Pembelajaran Menganalisis Struktur dan Kebahasaan Teks Eksposisi dengan Metode Think Pair And Share untuk Meningkatkan Kemampuan Berpikir Kritis pada Peserta Didik Kelas $X$ SMAN 6 Bandung Tahun Pelajaran 2018/2019"

Dari uraian di atas, penulis memberikan identifikasi masalah yang akan dijadikan bahan penelitian sebagai berikut:
1. Peningkatan minat membaca peserta didik;

2. Pemahaman peserta didik mengenai pentingnya membaca secara kritis untuk meningkatkan daya berpikir kritis;

3. Pemahaman Peserta didik mengenai pengertian, struktur dan kebahasaan teks eksposisi.

Dari permasalahan yang penulis identifikasikan, penulis memfokus-kan penelitian ini pada permasalahan yang telah dibahas dalam latar belakang masalah dan diidentifikasi dalam subbab ini.

Terarahnya suatu penelitian tak terlepas dari cara penulis merumuskan masalah-masalah yang muncul. penulis berharap, tepatnya perumusan suatu masalah mampu medukung terciptanya penelitin yang baik dan valid. Dari uraian latar belakang sebelumnya, penulis merumuskan masalah yang akan diteliti menjadi beberapa poin, yaitu:

1. Mampukah peneliti merencanakan, melaksanakan, dan menilai peserta didik dalam kegiatan menganalisis struktur teks eksposisi dengan menggunakan metode think pair and share pada 
peserta didik kelas $\mathrm{X}$ tahun pelajaran 2018/2019?

2. Mampukah peserta didik menganalisis struktur dan kebahasaan teks eksposisi dengan menggunakan metode think pair and share dalam proses pembeajaran di tahun pelajaran 2018/2019?

3. Apakah metode think pair and share efektif digunakan sebagai penunjang peserta didik dalam memahami struktur dan kebahasaan teks eksposisi?

4. Apakah hasil pembelajaran menganalisis struktur dan kebahasaan teks eksposisi dengan metode think pair and share untuk meningkatkan kemampuan berpi-kir kritis peserta didik lebih besar dibandingkan dengan kelas kon-trol yang menggunakan metode cermahdiskusi?

5. Apakah metode think pair and share pada kelas eksperimen lebih efektif digunakan untuk pembelajaran menganalisis struktur dan kebahasaan teks eksposisi dibandingkan dengan metode ceramahdiskusi pada kelas kontrol?

6. Apakah pembelajaran menganalisis struktur dan kebahasaan teks eksposisi dengan metode think pair and share untuk meningkatkan kemampuan berpi-kir kritis peserta didik kelas eksperimen lebih efektif disban-dingkan dengan kelas kontrol?

Merujuk dari uraian di atas penulis menemukan beberapa konsep yang harus penulis jadikan acuan untuk menjawab permasalahanpermasalahan yang telah dituliskan.

Penulis memiliki beberapa tujuan yang ingin dicapai setelah melakukan penelitian ini, antara lain:

1. untuk mengetahui keberhasilan pendidik dan peserta didik dalam melaksanakan pembelajaran menganalisis struktur dan kebahasaan teks eksposisi sebagai pada siswa kelas $x$ semester ganjil SMAN 6 Bandung untuk meningkatkan kemampuan berpikir kritis dengan menggunakan metode think pair and share.

2. untuk mengetahui kemampuan peserta didik kelas X SMAN 6 Bandung melakukan pembelajaran menganalisis struktur dan kebahasaan teks eksposisi untuk menigkatkan kemampuan berpi-kir kritis dengan menggunakan metode think pair and share. 
3. untuk mengetahui keefektifan metode think pair and share dalam pembelajaran menga-nalisis struktur dan kebahasaan teks eksposisi sebagai upaya meningkatkan kemampuan berpikir kritis pada peserta didik kelas $X$.

4. untuk mengetahui perbedaan hasil belajar antara pembelajaran menganalisi struktur dan teks eksposisi dengan metode think pair and share dan pembelajaran dengan menggunakan metode ceramah-diskusi?

5. untuk mengetahui kefektifan metode think pair and share dalam pembelajaran menga-nalisis struktur dan kebahasaan teks eksposisi dibandingkan dengan pembelajaran yang meng-gunkan metode ceramah-diskusi.

6. untuk mengetahui ketepatan pembelajaran menganalisi struktur dan kebahasaan teks eksposisi dengan metode think pair and share sebagai upaya meningkatkan kemampuan berpikir kritis peserta didik pada kelas ekspserimen jika dibandingkan dengan peserta didik pada kelas kontrol.
Berdasarkan uraian diatas, penulis mengupayakan tujuan yang tertulis dapat diraih dengan peneli-tian yang penulis lakukan.

Suatu kegiatan penelitian tentunya harus memberikan manfaat bagi peneliti maupun objek yang diteliti. Penulis memiliki harapan agar penelitian yang dilakukan bermanfaat bagi pembaca khususnya pendidik dan peserta didik.

\section{Manfaat Teoritis}

Secara teoritis, penelitian ini bermanfaat untuk mengetahui kemampuan peserta didik dalam memahami teks eksposisi berdasarkan struktur dan kaidah kebahasaan. Selain itu, penelitian ini mampu mengetahui tingkatan daya berpikir kri-tis peserta didik. Sehingga, bukan hanya pengetahuan mengenai teks, tapi mampu meningkatkan kemam-puan berpikir peserta didik.

\section{Manfaat Praktis}

Manfaat praktis merupakan manfaat yang diterima secara langsung dari hasil penelitian oleh semua pelaku yang terlibat dalam kegiatan penelitian maupun bagi yang membaca tulisan ini. Penerima 
manfaat khususnya meliputi pendi-dik, peserta didik, guru bahasa Indo-nesia. Namun,tidak menutup ke-mungkinan untuk masyarakat yang memiliki kepentingan pendidikan.

\section{a. Bagi Peneliti}

Bagi penelitian ini dapat dijadikan pelajaran, pengalaman dan saran berharga dalam usaha meningkatkan kinerja/kemampuan dalam melakukan praktik penelitian mengenai laporan pembelajaran menganalisis struktur dan kebahasaan teks eksposisi sebagai upaya meningkatkan hasil belajar dan kemampuan berpikir kritis dengan menggunakan metode think pair and share.

\section{b. Bagi Peserta Didik}

Ketika telah melaksanakan penelitian ini, dan siswa khusunya mampu mengaplikasikannya pada mata pelajaran lain untuk memudahkan peserta didik dalam proses pembelajaran yang lebih efektik, aktif, dan bervariatif sehingga mapu menciptakan proses belajar yang efektif dan inovatif serta menyenangkan. c. Bagi Guru Bahasa dan Sastra Indonesia

Setelah melaksanakan penelitian ini, apanila menemukan titik temu tentang keefektifan metode think pair and share. berharapa para pen-didik mampu menerapkannya dalam proses pembelajaran di kelas, karena tujuan dari metode ini ialah meningkatkan daya tangkap dan pemahaman siswa dalam memahami materi pelajaran yang disampaikan pendidik sehingga peserta didik mampu menyerap materi yang disampaikan secara menyeluruh.

Meskipun manfaat diatas dikhususkan untuk beberapa elemen. Namun tidak menutup kemungkinan bermanfaat juga untuk berbagai kalangan di luar proses belajar dalam kelas.

Adapun definisi operasional yang meliputi penjelasan istilah yang terdapat dalam judul penelitian, antara lain sebagai berikut:

1. Pembelajaran adalah proses interaksi antara peserta didik dengan guru dan sumber belajar pada suatu lingkungan belajar.

2. Menganalisis adalah suatu keterampilan membaca yang digunakan untuk mengetahui 
kesalahan dan kebenaran yang terdapat dalam sebuah teks.

3. Struktur adalah unsur-unsur yang terkandung dalam sebuah teks.

4. Kebahasaan adalah perihal kebahasaan yang terdapat pada teks.

5. Teks eksposisi merupakan teks yang menyajikan pendapat atau gagasan yang dilihat dari sudut pandangnya dan berfungsi meyakinkan pihak lain bahwa argumen-argumen yang disampaikannya itu dapat dipertanggungjawabkan.

6. Bepikir kritis merupakan kegi-atan kognitif yang bertujuan untuk menggali informasi dengan lengkap.

7. Model Think Pair and Share adalah metode pembelajaran yang mampu mengoptimalkan peserta didik untuk berpar-tisipasi dalam kegiatan belajar dan memecahkan suatu masalah secara individu, berpasangan, dan kelompok.

Berdasarkan definisi operasional di atas, penulis menyimpulkan bahwa pembelajaran menganalisis struktur dan kebahasaan teks eksposisi sebagai upaya meningkatkan hasil belajar dan kemampuan berpikir kritis dengan metode think pair and share merupakan kegiatan pembelajaran yang mampu meng-optimalkan peserta didik untuk ber-partisipasi dalam kegiatan belajar dan memecahkan suatu masalah secara individu, berpasangan, atau-pun kelompok sebagai upaya meningkatkan kemampuan berpikir kritis.

\section{B. METODE PENELITIAN}

Metode penelitian merupakan cara memecahan masalah penelitian yang dilaksanakan secara terencana dan cermat dengan maksud mendapatkan fakta dan simpulan agar dapat memahami, menjelaskan, meramalkan, dan mengendalikan keadaan (Syamsuddin dan Damayanti, 2011, hlm. 14). Sehingga, dengan adanya metode penelitian mendapatkan pemecahan dari masalah penelitian secara sistematis dan factual. Berkaitan dengan judul di dalam penelitian ini, maka metode yang digunakan adalah metode penelitian campuran (mix method) dengan bentuk paralel konvergen dengan pretes dan postes kelompok eksperimen dan kontrol data kuantitatif dan kualitatif. 
Metode penelitian campuran dapat diartikan sebagai metode penelitian yang digunakan untuk mencari pengaruh perlakuan tertentu terhadap yang lain dengan menggabungkan data kuantitatif dan kualitatif. Menurut Creswell (2017, hlm. 5) mengatakan " penelitian metode campuran merupakan pendekatan penelitian yang melibatkan pengumpulan data kuantitatif dan kualitatif, penggabungan dua bentuk data, dan penggunaan rancangan berbeda, yang dapat melibatkan asumsi-asumsi filosofis dan kerangka kerja teoritis". Sehing-ga, metode penelitian campuran melakukan penggabungan antara data kuantitatif dan kualitatif sehing-ga saling menguatkan untuk mendapatkan simpulan yang lebih lengkap.

Metode penelitian campuran yang digunakan penulis adalah metode campuran paralel konvergen. Creswell (2017, hlm. 294) mengatakan, "dalam pendekatan ini, seorang peneliti mengumpulkan data kualitatif dan kuantitatif, menganalisisnya secara terpisah, dan kemudian membandingkan hasil untuk melihat apakah temuan-temuan saling mengkonfirmasi atau tidak mengkonfirmasi". Penulis mengam-bil cara pengumpulan data dengan tes awal, perlakuan, dan tes akhir pada kelompok eksperimen dan tes awal dan tes akhir tanpa perlakuan pada kelompok kontrol. Penelitian ini membutukan 2 grup/kelas yaitu kelas eksperimen sebagai fokus penelitian dan kelas kontrol sebagai pembanding. Metode penelitian campuran digunakan dalam kegiatan penelitian ini untuk menguji pembelajaran menganalisis struktur dan kebahasaan teks eksposisi dengan menggunakan model pembelajaran think pair and share.

Pada penelitian ini, penulis menggunakan desain paralel konvergen berupa pengumpulan dan analisis daya kuantitatif, pe-ngumpulan dan analisis data kualitatif, membandingkan atau menghubungkan, lalu interpretasi. Desain penelitian paralel konvergen yang penulis kutip dari John W. Creswell. Desain diatas sangat cocok dengan penelitian yang penulis lakukan, karena penelitian yang penulis lakukan membutuhkan data kualitatif dan kuantitatif.

Populasi adalah keseluruhan objek penelitian. Berdasarkan hal 
tersebut, populasi dalam penelitian ini adalah:

a. Kemampuan penulis dalam melaksanakan pembelajaran menganalisis struktur dan kebahasaan teks eksposisi.

b. Kemampuan peserta didik kelas $X$ SMAN 6 Bandung dalam menganalisis struktur dan kebahasaan teks eksposisi dengan menggunakan model think pair and share.

c. Ketepatan model think pair and share dalam pembelajaran menganalisis struktur dan kebahasaan teks eksposisi guna meningkatkan kemampuan berpikir kritis pada peserta didik kelas $X$ SMAN 6 Bandung.

Subjek penelitian diatas merupakan hasil klasisifkasi penulis. Populasi keseluruhan yang dikelompokan berdasarkan objek yang akan diteliti.

Berdasarkan penjelasan di atas, sampel dalam penelitian penulis uraikan sebagai berikut :

a. Kemampuan penulis sehubungan dengan perencanaan, pelaksanaan, dan penilaian dalam pembelajaran menganalisis struktur, dan kebahasaan teks eksposisi dengan menggunakan model think pair and share.

b. Kemampuan peserta didik kelas $X$ SMAN 6 Bandung yang diukur adalah menganalisis struk-tur, dan kebahasaan eksposisi dengan menggunakan model think pair and share.

c. Keefektifan model pembelajaran think pair and share dalam meningkatkan kemampuan berpikir kritis peserta didik.

Pemaparan sampel diatas penulis susun berdasarkan pertimbangan yang disesuaikan dengan keefektifan proses penelitian yang terlaksana dengan baik dan sistematis sesuai kaidah peneltian yang konvensional.

Pada dasarnya, penelitian ini merupakan pengukuran pembelajaran peserta didik didalam kelas dengan tujuan meningkatkan hasil belajar. Adapun instrumen yang digunakan oleh penulis ialah sebagai berikut.

1. Observasi.

2. Rencana Pelaksanaan Pembelajaran.

3. Format penilaian perencana-an dan pelaksanaan pembelajran.

4. Tes. 
Rancangan analisis data yang dibuat oleh penulis adalah sebagai berikut.

1. Analisis hasil penilaian pretes dan postes.

2. Mencari rata-rata (mean) selisih dari pretes dan postes (Md).

3. Mencari jumlah deviasi dan kuadrat deviasi.

4. Mencari koefisien.

5. Melihat nilai pada tabel dengan taraf signifikansi $5 \%$ pada tingkat kepercayaan 95\%.

6. Menguji signifikasi koefisien.

7. Perbandingan hasil kelas kontrol dan eksperimen.

8. Pengorelasian hasil data kualitatif dan kuantitatif.

\section{HASIL PENELITIAN DAN PEMBAHASAN}

Hasil dan analisis data dilakukan oleh penulis setelah melakukan kegiatan penelitian. Penulis telah melakukan kegiatan penelitian yang sesuai dengan prosedur penelitian yang telah dijelaskan pada bab sebelumnya. Penulis telah mempersiapkan lima data yang telah penulis dapatkan dari kegiatan penelitian, yaitu: data hasil perencanaaan pem- belajaran, data hasil pelaksanaan pembelajaran, data hasil observasi kemampuan berpikir kritis peserta didik, data hasil pretes dari siswa, data hasil postes dari siswa.

Berdasarkan hasil analisis yang telah penulis laksanakan, maka hipotesis yang diajukan dibuktikan sebagai berikut.

Hipotesis pertama diterima. Hal ini dapat dibuktikan dengan hasil penilaian guru Bahasa Indonesia mengenai perencanaan dan pelaksanaan penulis merencanakan dan melaksanakan pembelajaran. Penulis mendapatkan nilai rata-rata pelaksanaan pembelajaran adalah 3.65 yang termasuk dalam kategori A (Baik sekali). Artinya, penulis mampu mengajarkan materi menganalisis struktur dan kebaha-saan teks eksposisi dengan metode think pair and share untuk meningkatkan kemapuan berpikir kritis pada peserta didik kelas X SMAN 6 Bandung.

Hipotesis kedua diterima. Hal ini dapat dibuktikan dengan hasil dari nilai rata-rata pretes kelas eksperimen 27,14 dan nilai rata-rata postes kelas eksperimen 82,28 . sedangkan pada kelas kontrol nilai rata-rata pretes 18 , dan nilai rata-rata postes 59,14 . Jadi, 
selisih rata-rata pretes dan postes kelas eksperimen adalah 55,14, sedangkan selisih rata-rata kelas kontrol adalah 41,14. Artinya, peserta didik kelas $\mathrm{X}$ mampu menganalisis struktur dan kebahasaan teks ekposisi dengan metode think pair and share.

Hipotesis ketiga diterima. Hal ini dapat dibuktikan berdasarkan hasil data uji $t$. Berdasarkan analisis data dan perhitungan yang telah dilakukan oleh penulis, diperoleh derajat kebebasan sebesar 24 dengan tingkat kepercarayaan $95 \%$ dan taraf signifikan $5 \%$ dengan hasil thitung $>$ tabel, yakni 25,53 >2,06. Artinnya, metode think pair and share sangat efektif digunakan untuk pembelajaran menganalisis struktur dan kebahasaan teks eksposisi karena dengan hasil thitung yang lebih besar.

Hipotesis keempat diterima. Mengenai perbedaan hasil belajar antara peserta didik kelas eksperimen dan kelas kontrol. Data pretes pada kelas eksperimen ialah skor minimal sebesar 14,29, selanjutnya skor maximum sebesar 42,86 , nilai total sebesar 678,59 dan nilai mean sebesar 27,14, selanjutnya data postes pada kelas eksperimen mendapatkan hasil skor minimal sebesar 71,43, selanjutnya skor maximum sebesar 92,86 , nilai total sebesar 2057,11 dan nilai mean sebesar 82,28 . Kemudian untuk data pretes pada kelas kontrol didapatkan hasil skor minimal sebesar 0 , selanjutnya skor maximum sebesar 42,86 , nilai total sebesar 450 dan nilai mean sebesar 18. Nilai postes kelas eksperimen dengan skor minimal sebesar 35,71, skor maksimal 85,71, nilai total sebesar 1478,55 , dan nilai mean sebesar 59,14. Artinya, terdapat perbedaan dan peningkatan yang berbeda diantara kelas eksperimen dan kelas kontrol.. Hasil data menunjukkan bahwa hasil belajar peserta didik di kelas eksperimen lebih baik, dibandingkan dengan hasil belajar peserta didik di kelas kontrol.

Hipotesis kelima diterima. Mengenai kefektifan metode think pair and share dibandingkan dengan metode ceramah-diskusi, dapat dilihat dari perbedaan hasil postes pada kelas eksperimen dan kelas kontrol. Kelas eksperimen mendapatkan nilai postes total sebesar 2057,11 dan nilai rata-rata sebesar 82,28 , sedangkan kelas kontrol mendapatkan nilai postes total postes sebesar 1478,55 dengan nilai rata-rata 59,14 . Data ini 
membuktikan bahwa kelas eksperimen yang mengunakan metode think pair and share memiliki keefektifan kegiatan belajar lebih tinggi dibandingkan dengan kelas kontrol.

Hipotesis keenam diterima. Mengenai perbandingan metode untuk melihat peningkatan antara kelas eksperimen yang menggunakan metode think pair and share dan kelas kontrol yang menggunakan metode ceramah-diskusi, dapat dilihat dari hasil pengamatan yang telah dilakukan oleh pendidik selama penelitian berlangsung pada kedua kelas. Pada kelas eksperimen, ratarata perolehan skor dari lembar pengamatan kemampuan berpikir kritis peserta didik sebanyak 25 orang termasuk pada kategori baik (B) karena dapat memenuhi aspek pengamatan kemampuan berpikir kritis dengan skor rata-rata 3,35. Kategori ini dilihat dari kriteria kemampuan berpikir kritis yang telah dirumuskan oleh penulis. Kelas kontrol dalam kemampuan berpikir kritis mendapatkan hasil dengan kategori sedang (C). Hal ini bisa dilihat dari tabel pengamatan dengan perolehan skor rata-rata 2,51 yang termasuk pada kategori sedang (C).
Demikianlah data dari hasil evaluasi yang telah penulis analisis. Data tersebut penulis dibuktikan melalui analisis yang akurat. Berdasarkan data dan analisis hasil evaluasi tersebut, dapat disimpulkan bahwa keenam hipotesis yang penulis ajukan dalam penelitian ini dapat diterima. Sehingga Pembe-lajaran Menganalisis Struktur dan Kebahasaan Teks Eksposisi dengan Metode Think Pair and Share untuk Meningkatkan Kemampuan Berpikir Kritis pada Peserta Didik Kelas $\mathrm{X}$ SMAN 6 Bandung Tahun Pelajaran 2018/2019 berahasil dilaksanakan oleh penulis.

\section{KESIMPULAN}

Penulis akan mengemukakan bebepara simpulan yang penulis dapatkan setelah melakukan kegiatan penelitian menganalisis struktur dan kebahasaan teks eksposisi dengan metode think pair and share untuk meningkatkan kemampuan berpikir kritis pada peserta didik kelas X SMA $N 6$ Bandung. Penulis mengambil simpulan berdasarkan data yang penulis dapatkan dari mulai perencanaan sampai pelaksanaan. 
Simpulan yang penulis dapatkan ialah sebagai berikut:

1. Penulis mampu merencanakan, melaksanakan, dan menilai pembelajaran menganalisis struktur dan kebahasaan teks eksposisi dengan menggunakan metode Think Pair and Share pada Peserta didik kelas X SMA N 6 Bandung tahun pelajaran 2018/2019. Keberhasilan ini dapat dilihat dari hasil penilaian guru mata pelajaran Bahasa Indonesia terhadap penulis dengan rata-rata nilai kumulatif perencanaa dan pelaksanaan sebesar 3,65 yang termasuk ke dalam kategori baik sekali $(A)$.

2. Peserta didik kelas X SMA N 6 Bandung mampu mengikuti pembelajaran menganalisis struktur dan kebahasaan teks eksposisi dengan menggunakan metode Think Pair and Share. Ketercapaian ini dapat dilihat dari hasil rata-rata pretes sebesar 27,14 dan postes sebesar 82,28 pada kelas eksperimen.

3. Metode pembelajaran Think Pair and Share lebih tepat digunakan pada peserta didik untuk pembelajaran menganalisis struktur dan kebahasaan teks eksposisi.
Hal ini dapat dibuktikan berdasarkan hasil data uji $t$. Ber-dasarkan analisis data dan perhitungan yang telah dilakukan oleh penulis, diperoleh derajat kebebasan sebesar 24 dengan tingkat kepercarayaan 95\% dan taraf signifikan $5 \%$ dengan hasil thitung >ttabel, yakni 25,53 > 2,06.

4. Perbedaan hasil belajar kelas eksperimen yang menggunakan metode think pair and share lebih besar dibandingkan hasil belajar pada kelas kontrol yang menggunakan metode ceramah-diskusi. Perbedaan hasil belajar dapat dilihat dari perbedaan hasil yang diperoleh oleh kedua kelas. Data pretes pada kelas eksperimen ialah skor minimum sebesar 14,29, selanjutnya skor maximum sebesar 42,86 , nilai total sebesar 678,59 dan nilai mean sebesar 27,14, selanjutnya data postes pada kelas eksperimen menda-patkan hasil skor minimum sebesar 71,43, selanjutnya skor maximum sebesar 92,86 , nilai total sebesar 2057,11 dan nilai mean sebesar 82,28. Kemudian untuk data pretes pada kelas kontrol didapatkan hasil skor minimum sebesar 0 , selanjutnya 
skor maximum sebesar 42,86 , nilai total sebesar 450 dan nilai mean sebesar 18. Nilai postes kelas eksperimen dengan skor minimum sebesar 35,71, skor maksimun 85,71 , nilai total sebesar 1478,55 , dan nilai mean sebesar 59,14.

5. Metode think pair and share sangat efektif digunakan untuk pembelajaran menganalisis struktur dan kebahasaan teks ekposisi dibandingkan metode ceramah-diskusi. Mengenai keefektifan metode think pair and share dibandingkan dengan metode ceramah-diskusi, dapat dilihat dari perbedaan hasil postes pada kelas eksperimen dan kelas kontrol. Kelas eksperimen mendapatkan nilai postes total sebesar 2057,11 dan nilai rata-rata sebesar 82,28 , sedangkan kelas kontrol mendapatkan nilai postes total postes sebesar 1478,55 dengan nilai rata-rata 59,14. Data ini membuktikan bahwa kelas eksperimen yang mengunakan metode think pair and share memiliki keefektifan kegiatan belajar lebih tinggi dibandingkan dengan kelas kontrol.
6. Pembelajaran menganalisis struktur dan kebahasaan teks eksposisi dengan metode think pair and share sangat tepat digunakan untuk meningkatkan kemampuan berpikir kritis peserta didik kelas eksperimen dibandingkan kelas kontrol. Pada kelas eksperimen, rata-rata perolehan skor dari lembar pengamatan kemampuan berpikir kritis peserta didik sebanyak 25 orang termasuk pada kategori baik (B) karena dapat memenuhi aspek pengamatan kemampuan berpikir kritis dengan skor rata-rata 3,35. Kategori ini dilihat dari kriteria kemampuan berpikir kritis yang telah dirumuskan oleh penulis. Kelas kon-trol dalam kemampuan berpikir kritis mendapatkan hasil dengan kategori sedang $(\mathrm{C})$. Hal ini bisa dilihat dari tabel pengamatan dengan perolehan skor rata-rata 2,51 yang termasuk pada kategori sedang (C).

Berdasarkan simpulan yang penulis kemukakan di atas, penulis meyakini bahwa pembelajaran yang penulis lakukan sangat efektif. Penulis membuat proses pembe-lajaran yang kreatif dan menyenangkan 
dengan menggunakan metode pembelajaran yang variatif, sehingga dapat menunjang ke dalam pencapaian tujuan pembelajaran dan hasil belajar peserta didik.

Berdasarkan kegiatan penelitian yang telah penulis lakukan, penulis memberikan saran kepada pendidik agar lebih kreatif dalam melakukan kegiatan mengajar terhadap peserta didik, karena ketepatan metode yang digunakan dalam proses pembelajaran sangat berdampak positif bagi ketercapaian tujuan pembelajaran yang diinginkan. Terbukti dengan ketepatan pemilihan metode yang penulis lakukan terhadap peserta didik mampu menciptakan proses belajar yang baik dan meningkatkan hasil belajar peserta didik sehingga dapat mencapain tujuan pembelajaran.

Mengacu pada peran pendidik sebagai komponen yang membetuk peserta didik agar berkarakter, berpengatahuan, dan berpendidikan yang baik, pendidik harus mampu membaca kondisi yang terjadi dan menyesuaikannya dengan pembelajaran yang akan dilakukan. Tujuan dari hal itu agar pendidik dapat menstimulus peserta didik untuk mengitu pembelajaran. Peran pendidik dalam merumuskan perencanaan dan pelaksanaan pembelajaran sangat penting bagi kelangsungan belajar dan motivasi belajar peserta didik. Saran dari penulis pembelajaran saat ini pendidik harus bisa menciptakan proses pembelajaran yang sesua dengan tujuan pendidikan, kondisi peserta didik, lingkungan, dan per-kembangan teknologi yang terjadi.

\section{DAFTAR PUSTAKA}

Alwasilah, dkk. (2005). Pokoknya menulis (cara baru menulis dengan metode kolaborasi). Bandung: Kiblat.

Arifin, Samsul. (2017). Pembelajaran mengontruksi teks eksposisi dengan menggunkan media gambar seri pada sisiwa kelas $x$ sman 16 bandung tahun pelajaran 2017/2018. Universitas Pasundan: Tidak Diterbitkan

Cahyadi, Asep. 92016. Pembelajaran membandingkan teks laporan hasil observasi dengan teks eksposisimenggunakan model think pair and share pada siswa kelas $x$ sman 18 bandung tahun pelajaran 2016/2017. Universitas Pasundan: Tidak Diterbikan.

Creswell, John W. (2017). Research design: pendekatan metode kualitatif, kuantitatif, dan 
campuran. Edisi 4. Yogyakarta: Pustaka Pelajar.

Fisher, A. (2008). Berpikir kritis: sebuah pengantar. Jakarta: Erlangga

Huda, Miftahul (2016). Model-model pengajaran dan pembelajaran. Yogyakarta: Pustaka Pelajar.

Joko, M. (2007). Kurikulum tingkat satuan pendidikan manajemen pelaksanaa dan kesiapan sekolah menyongsongnya. Yogyakarta: Pustaka Pelajar.

Komalasari, K. (2013). Pembelajaran kontekstual konsep dan aplikasi. Bandung: PT Refika Aditama.

Kosasih, E. (2016). Jenis-jenis Teks. Bandung: Yrama Widya.

Kunandar (2015). Penilaian auntentik. Jakarta: Rajawali Pers.

Kuncoro, Mudrajad. (2009) Mahir menulis. Jakarta: Erlangga.

Majid, A. (2014). Implementasi kurikulum 2013. Bandung: Interes.

Majid, Chaerul R. (2014). Pendekatan ilmiah ( dalam implementasi kurikulum 2013). Bandung: PT. Remaja Rosdakarya.

Marpuah, Dewi Intan. (2017). pembelajaran menelaah struktur dan kebahasaan teks ulasan karya seni daerah yang dibaca dengan menggunakan model think pair share di kelas VIII E SMP Negeri 2 Bandung tahun pelajaran

2017/2018.
Universitas Pasundan: Tidak Diterbitkan.

Mulyasa, E.(2013). Pengembangan dan implementasi kurikulum 2013. Bandung: PT. Remaja Rosda karya.

Mulyasa, E. (2008). Menjadi guru profesional menciptakan pembelajaran kreatif dan menyenangkan. Bandung: PT. Remaja Rosdakarya.

Peraturan Menteri Pendidikan Nasional Nomor 24 Tahun 2016 Tentang

Kompetensi Inti dan Kompetensi Dasar Pelajaran pada Kurikulum 2013

pada Pendidikan Dasar dan Pendidikan Menengah.

Qodratillah, M. T. (2011). Kamus bahasa indonesia untuk pelajar. Jakarta:

Badan Penagembangan dan Pembinaan Bahasa, Kementerian Pendidikan dan Kebudayaan.

Rudiana, Nur Is. 2015. Improving critical thinking skills through the application of the deep dialog critical thinking learning model in economics learning for students of SMKN 1 Yogyakarta. UNY: Tidak diterbitkan.

Shoimin, Aris. (2014) 68 Model pembelajaran inovatif dalam kurikulum 2013. Yogyakarta: ArRuzz Media.

Sitohang, Kasdin dkk. 2012. Critical thinking membangun pemikiran logis. Jakarta: PT. Pustaka Sinar Harapan. 
Sugono, dkk. (2008). Kamus Besar Bahasa Indonesia

Edisi Keempat. Jakarta: PT Gramedia Pustaka Utama.

Tampubolon, DP. (1990). Kemampuan membaca teknik membaca efektif dan efisien. Bandung: Angkasa.

Tarigan, H.G. (2008). Membaca sebagai suatu keterampilan berbahasa.

Bandung: Angkasa.

Tim Kemendikbud. (2017). Bahasa Indonesia (untuk SMA/MA/SMK/MAK Kelas X). Jakarta: Kementerian Pendidikan dan Kebudayaan, 2017.

Syamsuddin, Damaianti. (2011). Metode penelitian pendidikan bahasa. Bandung: Rosdakarya.

Sugiyono. (2016). Metode penelitian kombinasi (mixed methods).Bandung: Alfabeta.

Sugiyono. (2016). Metode penelitian kuantittif, kualitatif, dan R\&D. Bandung: Alfabeta. 